\title{
Evaluation of Potential Sites for Harnessing Tidal Energy around Coastal Area of Malaysia
}

\author{
Nazani Nazri ${ }^{1,}$, Shahrani Anuar ${ }^{1}$, Firdaus Basrawi ${ }^{1}$, Ahmmad Shukrie $^{1}$, Siti Aishah ${ }^{1}$ \\ ${ }^{1}$ Energy Sustainable Focus Group (ESFG), 26600 Pekan, Malaysia.
}

\begin{abstract}
This paper present the potential sites around coastal area of Malaysia for electricity generation by harnessing tidal energy. As the electricity demand increase over the year and generating electricity by using fossil fuel caused the increase number in $\mathrm{CO}_{2}$ emission, thus renewable energy become one of the solution for alternating energy for electricity. There are a few of identified locations along Malaysia's coastal area that have potential for tidal energy implementation. The approaching for harnessing tidal energy are by using tidal barrage approach which are consist three types of mode generation ebb-mode, flood-mode and double-mode. The output generations are calculated by identify the size of basin at identified locations. For suitable location identification is by using geographical map and bathymetry map. At the end, the identified location that suitable for harnessing tidal energy are Pulau Langkawi, Pulau Pinang, Lumut, Miri, Kota Kinabalu, Kudat, Lahad Datu, Tawau and Labuan.
\end{abstract}

\section{Introduction}

Renewable energy become one of the energy source that many countries looking for nowadays for electricity generation [1]. This is because, many countries still depend on the fossil fuel for electricity generation to fulfil the demands however, by using this energy source it will increase the number of $\mathrm{CO}_{2}$ emission as the demands increased that caused the global warming [2]. As a developing country, Malaysia population of 27.4 million in 2007 with an average annual growth rate of $1.8 \%$ will reach to 33.4 million by the year 2020 and approximately 37.4 million in 2030. In 2009, the total electrical energy generated was 103.2 TWh and the demand is expected to increase by $4.7 \%$ per annum to $274 \mathrm{TWh}$ by the year 2030. It will heavily influenced by strong demands from the industrial and residential sectors as Malaysia enters into an industrialized nation, whereby per capita electricity demand is expected to reach $7571 \mathrm{kWh} /$ person in the year 2030, more than double from 2002 [3].

As earth $70 \%$ covered by the ocean, it's become one of the renewable energy sources that available on the earth. The potential and commercial viability of harnessing tidal energy in Malaysia is not studied thoroughly. Until recently, a preliminary study was carried out to explore the potential of harnessing tidal energy in Malaysia for electricity generation [4]. Tidal energy is harnessed by using tidal barrage either by (a) Single-basin or (b) Double-

\footnotetext{
*Corresponding author: mnazani@gmail.com
} 
basin. For the single-basin tidal barrage there are three types which are (a) Ebb-mode generation (b) Flood-mode generation and (c) Double-mode generation [5].

Tidal barrage is a physical barrier namely the barrage, is created within the sea with Sluice Gates to control the flow of seawater [7, 8]. The Sluice Gates are to be closed at high tide so that the water level inside the barrage is held at its highest level. As the tide recedes, a difference in water level in between the barrage and the sea is created. The potential energy from the water level difference can then drive turbines to generate electricity [6].

Table 1. Fuel mix in electricity generation, 2000-2010 [3].

\begin{tabular}{|l|l|l|l|l|l|l|}
\hline \multirow{2}{*}{ Year } & \multicolumn{4}{|l|}{ \% of total } & \multirow{2}{*}{ Total (GWh) } \\
\cline { 2 - 6 } & Oil & Coal & Gas & Hydro & Others & \\
\hline 2000 & 4.2 & 8.8 & 77.0 & 10.0 & 0.0 & 69,280 \\
\hline 2005 & 2.2 & 21.8 & 70.2 & 5.5 & 0.3 & 94,299 \\
\hline 2010 & 0.2 & 36.5 & 55.9 & 5.6 & 1.8 & 137,909 \\
\hline
\end{tabular}

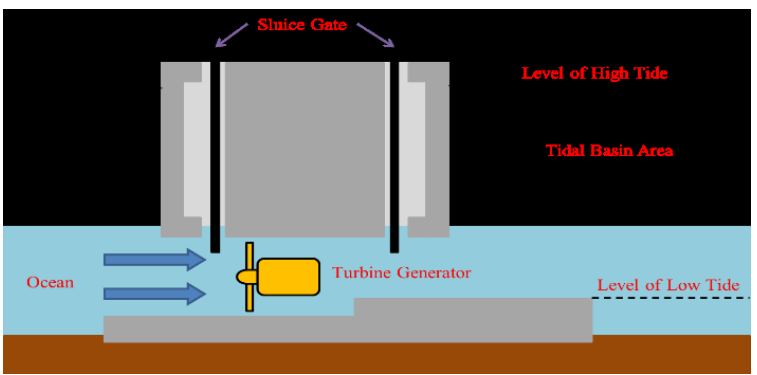

Fig. 1. Tidal barrage [6].

There are 16 tides station around coastal area of Malaysia not included with the east-coast region, which provided the tides range data which are Pulau Langkawi, Pulau Pinang, Lumut, Pelabuhan Kelang, Tanjung Keling, Kukup, Johor Bahru, Sejingkat, Bintulu, Miri, Kota Kinabalu, Kudat, Sandakan, Lahad Datu, Tawau and Labuan. These data is an annual data publication by Department of Survey and Mapping, Malaysia. From these data, an annual estimation output can be calculated.

The objective of this paper is to present the results of the assessment which are critical to policy makers and the potential investors on tidal energy in Malaysia for decision making. The results may help the neighboring countries to realize the possible potential of their ocean energy. This paper will begin with a brief introduction to the means of generating tidal data, followed by the characteristics of tides around Malaysia and the potential amount of electricity generation by tidal energy.

\section{Data collection}

First of all, before proceeding with the identification or selecting of potential site it will go through with data collection. There is a certain data that must be considered for calculating the output power generation because the purpose of the harnessing tidal barrage is to generate the electricity that can meet the local demand. The data are (a) tides range, (b) number of household and (c) electricity demand.

\subsection{Tides range}

The data collected from the Department of Survey and Mapping Malaysia, shows that the highest tidal range of almost three meters is located at Sabah and Sarawak. Malaysia has 21 
stations of tide gauge installation installed near to village or town. The purpose of tide gauge installation near village or town is to avoid and give warning if there is a change in increasing water level as usual that may cause flood to the nearest region. Since the tide gauge located near and at the coastal area, there will be advantage to make analysis of tidal range at nearest location of tide gauge station $[9,10,11,12,13]$.

Fig. 2. Tidal stations location.

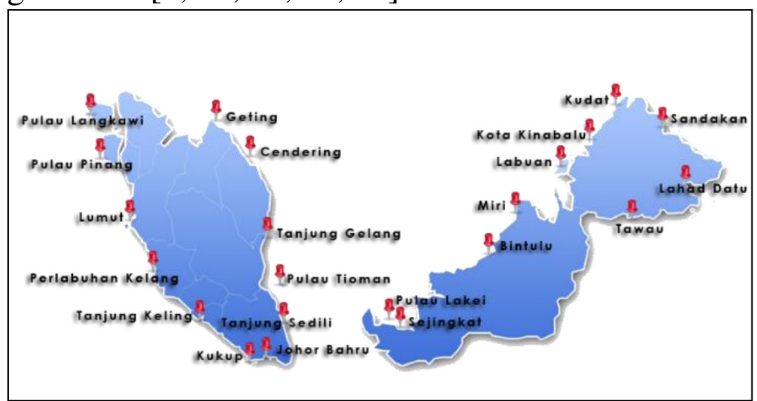

Tidal range can be defined from the tide different during the phase of flood and ebb tides. This different in height of tide can be further calculate for the tidal power generation. Figure 4 shows the average of tidal range difference of year 2011.

$$
\text { Flood Generation }=\mid \text { high tides }- \text { low tides } \mid
$$

$$
\text { Ebb Generation }=\mid \text { low tides }- \text { high tides } \mid
$$

Tidal range in Malaysia's coastal area not as high as the others countries that implement tidal barrage, however it is still reasonable to study and propose that this tidal energy in Malaysia because there are some places that identified as potential sites for harnessing tidal energy. As show in Table 2 the tides range for all locations in Malaysia.

Table 2. Tidal range in Malaysia [9, 10, 11, 12, 13].

\begin{tabular}{lccc}
\hline \multirow{2}{*}{ Tide Stations } & Mean Sea Level, $(\mathrm{m})$ & \multicolumn{2}{c}{ Tidal range $(\mathrm{m})$} \\
\cline { 3 - 4 } & & Ebb & Flood \\
\hline Pulau Langkawi & 2.17 & 1.80 & 1.79 \\
Pulau Pinang & 2.65 & 1.38 & 1.38 \\
Lumut & 2.16 & 1.63 & 1.63 \\
Pelabuhan Kelang & 3.61 & 3.06 & 3.07 \\
Tanjung Keling & 2.83 & 1.31 & 1.32 \\
Kukup & 4.01 & 1.98 & 1.98 \\
Johor Bahru & 2.87 & 1.92 & 1.91 \\
Sejingkat & 2.41 & 2.98 & 2.98 \\
Bintulu & 2.84 & 0.90 & 0.88 \\
Miri & 2.82 & 0.89 & 0.84 \\
Kota Kinabalu & 2.23 & 0.95 & 0.90 \\
Kudat & 2.31 & 1.04 & 0.97 \\
Sandakan & 5.68 & 1.04 & 0.99 \\
Lahad Datu & 1.90 & 1.14 & 1.14 \\
Tawau & 2.18 & 1.72 & 1.73 \\
Labuan & 2.53 & 1.01 & 0.95 \\
\hline
\end{tabular}




\subsection{Number of household and electricity demand}

The average electricity consumption in Malaysia is assumed $3966 \mathrm{kWh}$ per household annually $[14,15]$. By using assumed electricity consumption, then amount of electricity demands by local population is calculated and shown in the Table 2.

Table 3. Local electricity demand $[14,15]$.

\begin{tabular}{llll}
\hline Location & Mukim & $\begin{array}{l}\text { No. of } \\
\text { household }\end{array}$ & $\begin{array}{l}\text { Demand } \\
\text { (GWh) }\end{array}$ \\
\hline P.Langkawi & P.Langkawi & 26,000 & 103.12 \\
P.Pinang & Georgetown & 64,653 & 256.41 \\
Lumut & Lumut & 16,591 & 65.80 \\
P.Kelang & Kelang & 3,447 & 13.67 \\
Tg. Keling & Tg. Keling & 2,991 & 11.86 \\
Kukup & Serkat & 1,976 & 7.84 \\
J.Bahru & Sg. Tiram & 3,703 & 14.69 \\
Sejingkat & Padawan & 6,636 & 26.32 \\
Bintulu & Sebauh & 35,274 & 139.90 \\
Miri & Sibuti & 11,958 & 47.43 \\
K.Kinabalu & Tambunan & 81,747 & 324.21 \\
Kudat & Pitas & 16,745 & 66.41 \\
Sandakan & Tongod & 64,194 & 254.60 \\
Lahad Datu & Kunak & 34,179 & 135.55 \\
Tawau & Nabawan & 69,656 & 276.26 \\
Labuan & W.P.Labuan & 19,719 & 78.21 \\
\hline
\end{tabular}

From Table 2, the highest electricity demand is Kota Kinabalu follow by Tawau, Pulau Pinang, Sandakan, Bintulu, Lahad Datu and Pulau Langkawi which is the demands exceed more than $100 \mathrm{GWh}$ annually. While, the rest locations are below $100 \mathrm{GWh}$.

\section{Sites selection}

For the site selection, there are two types of maps that will be used which are (a) geographical map and (b) bathymetry map.

\subsection{Geographical map}

Geographical map normally used to see the type of earth structure on that particular selection area and observe the population pattern, population activities and development. This important before make a site selection for tidal barrage implementation.

Geographical map that has been used are from Google Earth and Google Map. Figure followed shows the selection area for Pulau Langkawi, Pulau Pinang, Lumut, Pelabuhan Kelang, Tanjung Keling, Kukup, Johor Bahru, Sejingkat, Bintulu, Miri, Kota Kinabalu, Kudat, Sandakan, Lahad Datu, Tawau and Labuan.

From these map, the type of earth structure and population activities are examining in order to see either that location are suitable for harnessing tidal energy for electricity or not. 


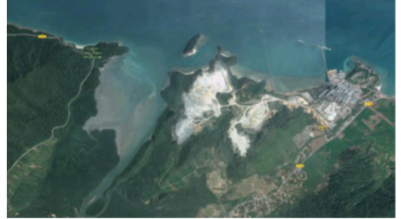

Fig. 3. Pulau Langkawi [16].

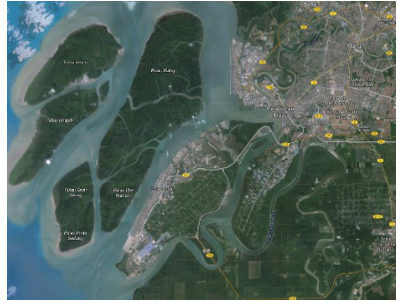

Fig. 6. Pelabuhan Kelang [19].

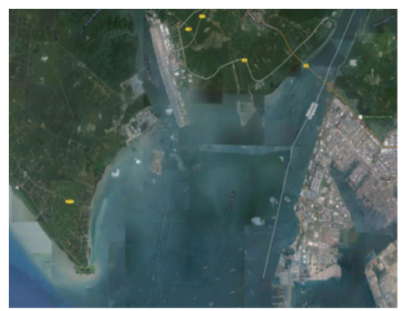

Fig. 9. Johor Bahru [22].

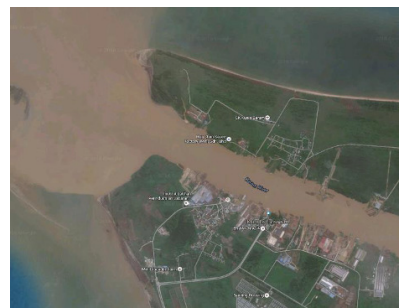

Fig. 12. Miri [25].

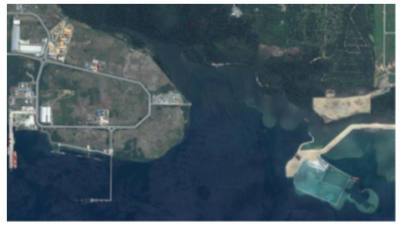

Fig. 15. Lahad Datu [29].

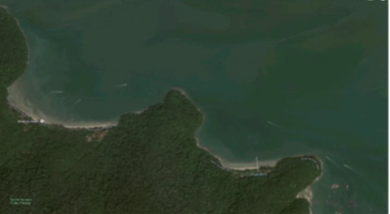

Fig. 4. Pulau Pinang [17].

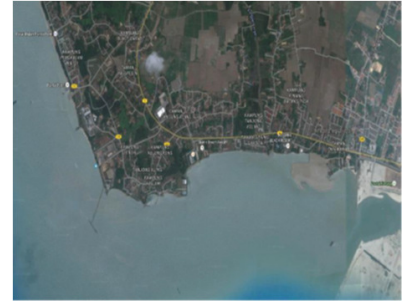

Fig. 7. Tanjung Keling [20].

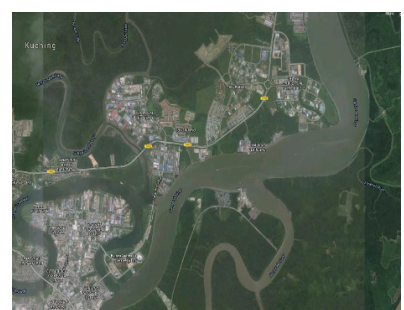

Fig. 10. Sejingkat [23].

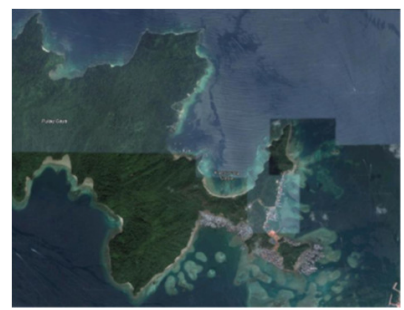

Fig. 13. Kota Kinabalu [26].

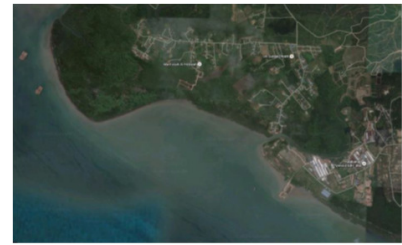

Fig. 16. Tawau [30].

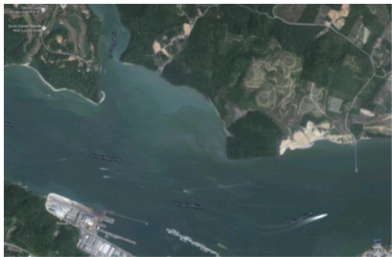

Fig. 5. Lumut [18].

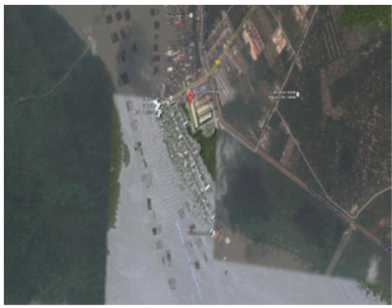

Fig. 8. Kukup [21].

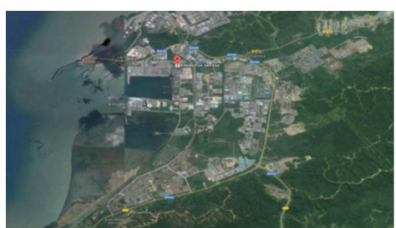

Fig. 11. Bintulu [24].

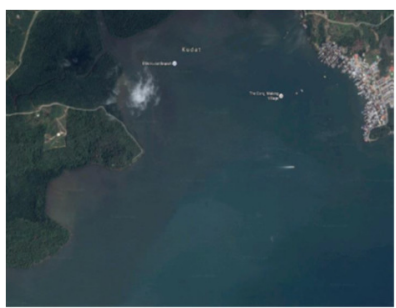

Fig. 14. Kudat [27].

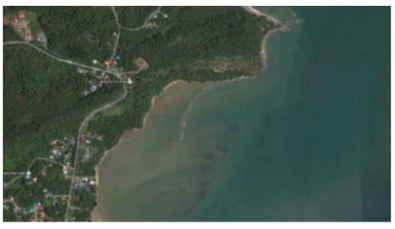

Fig. 17. Labuan [31].

From 16 suggested locations, only 9 places that identified as suitable for harnessing tidal barrage which are Pulau Langkaw, Pulau Pinang, Lumut, Miri, Kota Kinabalu, Kudat, Lahad Datu, Tawau and Labuan.

The suggested tidal basin area, Ab are Pulau Langkawi $\left(1.55 \mathrm{~km}^{2}\right)$, Pulau Pinang $(0.50$ $\left.\mathrm{km}^{2}\right)$, Lumut $\left(0.77 \mathrm{~km}^{2}\right)$, Miri $\left(0.66 \mathrm{~km}^{2}\right)$, Kota Kinabalu $\left(2.40 \mathrm{~km}^{2}\right)$, Kudat $\left(0.22 \mathrm{~km}^{2}\right)$, Lahad Datu $\left(1.50 \mathrm{~km}^{2}\right)$, Tawau $\left(0.80 \mathrm{~km}^{2}\right)$ and Labuan $\left(0.07 \mathrm{~km}^{2}\right)$ respectively. 


\subsection{Bathymetry Map}

When the potential locations is identified in the Google Map, the next step is to study and examine the characteristic of the coastal area on that location. The important data that very needed the most is bathymetry. Bathymetry data give the information of the sea level on that area which is very important in order to decide either that place suitable for tidal barrage implementation or not.

This is because, the minimum bathymetry requirement for the tidal barrage implementation is about 3 metres. When the bathymetry is higher is will give in result for higher tides range, which is result for the higher potential energy. When the potential energy created from tides is higher it will generate higher installed capacity and output power generation for electricity.

Even Malaysia's coastal area only have a few locations that achieved the minimum requirement, but it still consider as the potential area because Malaysia consists a few number of natural lagoon.

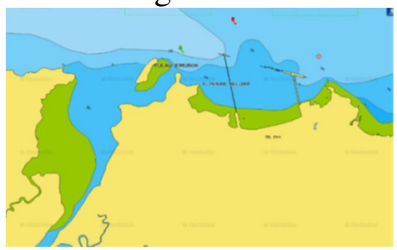

Fig. 18. Bathymetry of Pulau Langkawi [33].

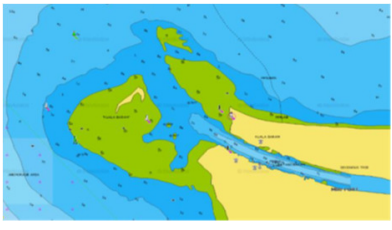

Fig. 21. Bathymetry of Miri [33].

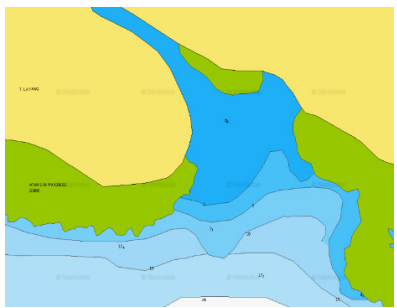

Fig. 24. Bathymetry of Lahad Datu [33].

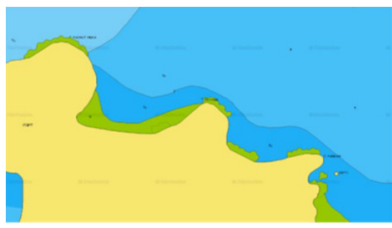

Fig. 19. Bathymetry of Pulau Pinang [33].

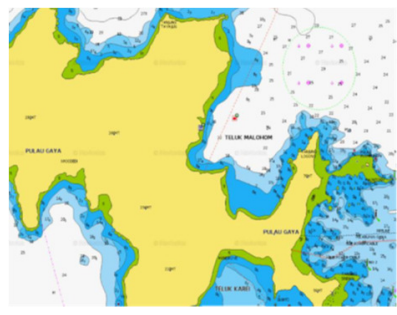

Fig. 22. Bathymetry of Kota Kinabalu [33].

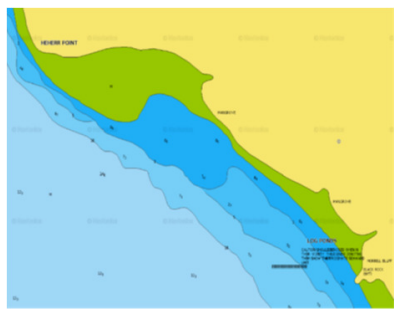

Fig. 25. Bathymetry of Tawau [33].

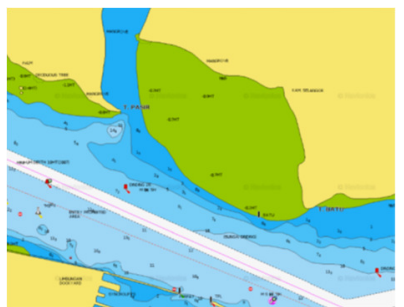

Fig. 20. Bathymetry of Lumut [33].

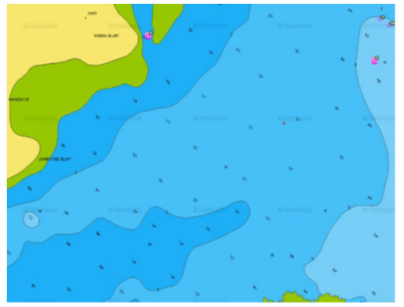

Fig. 23. Bathymetry of Kudat [33].

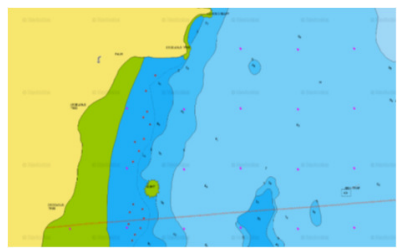

Fig. 26. Bathymetry of Labuan [33].

\section{Output power generation estimation}

The tide contains both potential and kinetic energy. The potential energy is the work done in lifting the mass of water above the ocean surface. The energy available from a barrage 
depends on the area of the water surface impounded by the barrage and the corresponding magnitude of the tidal range. The potential energy contained in the water volume impounded in a basin, can be expressed as:

$$
E_{P}=0.5 \rho g A_{b} \Delta h_{b}^{2}
$$

Where $E_{p}=$ potential energy over a tide cycle $(\mathrm{GJ}) ; \rho=$ density of sea water $\left(\mathrm{t} / \mathrm{m}^{3}\right) ; g=$ acceleration due to the Earth's gravity $\left(9.807 \mathrm{~m} / \mathrm{s}^{2}\right) ; A_{b}=$ horizontal area of the enclosed basin $\left(\mathrm{km}^{2}\right)$; and $\Delta h_{b}=$ mean tidal range in the basin $(\mathrm{m})$. The density of sea water varies from 1.021 to $1.030 \mathrm{t} / \mathrm{m}^{3}$, and is typically assumed to be $1.025 \mathrm{t} / \mathrm{m}^{3}$. The coefficient of $0.5 \mathrm{in}$ Eq. (1) is due to the fact that as the water in the basin is released through the turbines, the water head across the dam will be reduced accordingly. The maximum available head only occurs at the moment of low water, assuming that a high water level is still present in the basin. It can be seen from Eq. (1) that different tidal ranges influence greatly the value of the potential energy, and the magnitude of the mean tidal range and the value of the impounded area are the most important factors that determine the feasibility of a tidal barrage in terms of the annual energy output.

For coastal regions where tidal power generation is economically attractive, the tidal regime generally consists of two flood and two ebb tides, with a semi-diurnal period of 12.42 hours. At low tide the potential energy is zero. Therefore, the total potential energy per day from the barrage approximates to:

$$
E_{\text {total }}=\frac{24}{12.42} \times E_{P}
$$

and the corresponding mean potential power can be written as:

$$
\begin{aligned}
& P=\frac{24}{12.42} E_{P} / 86,400 \\
& P=1.1244 \times 10^{-4}\left(A_{b} \cdot \Delta h_{b}^{2}\right)
\end{aligned}
$$

in which $P$ is in GW. Tidal energy projects are characterized by low values of power conversion efficiency of g, usually ranging from $20 \%$ to $40 \%$, with an average of $33 \%$ often being used. Therefore, the potential annual tidal energy output from a barrage can be approximately calculated as:

$$
E_{\text {year }}=0.987 A_{b} \Delta h_{b}^{2} \eta
$$

Where Eyear in GWh.

\section{Result and discussion}

\subsection{Tidal basin area power generation}

Figure 6 shows the local demand for electricity and power generation from tidal barrage by using double-mode of generation. From the figure, it is shown that by using double-mode generation it can at least satisfy the electricity demand from the local usage compare to by using ebb-mode generation and flood-mode generation.

Double-mode generation can produce the higher output power generation because of the way it operates. The operation is combinational of the ebb-mode generation and flood-mode generation, from this the operations it is almost a continuous proses if compare to the ebb- 
mode generation and flood-mode generation that are only operate at one time of tides process which are during ebbs and floods.

Table 4. Output power generation.

\begin{tabular}{|c|c|c|c|c|}
\hline \multirow[t]{2}{*}{ Location } & \multirow{2}{*}{$\begin{array}{l}\text { Basin } \\
\text { Area, } \\
A_{b} \\
\left(\mathrm{~km}_{2}\right)\end{array}$} & \multicolumn{3}{|c|}{$\begin{array}{l}\text { Output power generation, } \\
\text { Pelectricity }(\mathrm{GWh})\end{array}$} \\
\hline & & Ebb & Flood & Double \\
\hline P.Langkawi & 1.55 & 1.94 & 1.92 & 2.99 \\
\hline P.Pinang & 0.50 & 0.40 & 0.39 & 0.61 \\
\hline Lumut & 0.70 & 0.77 & 0.77 & 1.19 \\
\hline P.Kelang & N/A & - & - & - \\
\hline Tg. Keling & N/A & - & - & - \\
\hline Kukup & N/A & - & - & - \\
\hline J.Bahru & N/A & - & - & - \\
\hline Sejingkat & N/A & - & - & - \\
\hline Bintulu & N/A & - & - & - \\
\hline Miri & 0.66 & 0.17 & 0.15 & 0.25 \\
\hline K.Kinabalu & 2.40 & 0.73 & 0.68 & 1.09 \\
\hline Kudat & 0.22 & 0.08 & 0.08 & 0.12 \\
\hline Sandakan & N/A & - & - & - \\
\hline Lahad Datu & 1.50 & 0.83 & 0.83 & 1.28 \\
\hline Tawau & 0.80 & 1.01 & 1.01 & 1.56 \\
\hline Labuan & 0.07 & 0.03 & 0.02 & 0.04 \\
\hline
\end{tabular}

Once the output power generation is calculated with suggested tidal basin area, the result is compare to the local demand and number of household on that locations. This is for comparison to see how much the contribution of harnessing tidal energy for electricity could supply for local population. Table 4 shows the comparison and contribution of the output power generation from tidal energy by using double-mode generation.

From Table 4, the highest power generation and percentage of contribution are Pulau Langkawi with output power generation $2.99 \mathrm{GWh}$ and could supplied to 753 houses with $2.90 \%$ of contribution from the whole number of household on that area. Then followed by Lahad Datu with $1.28 \mathrm{GWh}, 322$ household supplied and $0.94 \%$ of contribution. The lowest output power generation are in Labuan with $0.04 \mathrm{GWh}$ of power generation, only 10 houses supplied from output power generated and percentage of contribution $0.05 \%$.

Table 5. Number of house supplied by tidal energy and percentage of contribution.

\begin{tabular}{llll}
\hline Location & $\begin{array}{l}\text { Power } \\
\text { generation, } \\
\text { GWh }\end{array}$ & $\begin{array}{l}\text { House } \\
\text { supplied }\end{array}$ & $\begin{array}{l}\text { \% of } \\
\text { contribution }\end{array}$ \\
\hline P.Langkawi & 2.99 & 753 & 2.90 \\
P.Pinang & 0.61 & 153 & 0.23 \\
Lumut & 1.19 & 300 & 1.81 \\
P.Kelang & - & - & - \\
Tg. Keling & - & - & - \\
Kukup & - & - & - \\
J.Bahru & - & - & - \\
Sejingkat & - & - & - \\
Bintulu & - & - & - \\
Miri & 0.25 & 63 & 0.53 \\
K.Kinabalu & 1.09 & 274 & 0.34 \\
Kudat & 0.12 & 30 & 0.18 \\
Sandakan & - & - & - \\
Lahad Datu & 1.28 & 322 & 0.94 \\
Tawau & 1.56 & 393 & 0.56 \\
Labuan & 0.04 & 10 & 0.05 \\
\hline
\end{tabular}




\section{Conclusions}

In this paper, it was attempted to study the potential of harnessing tidal energy for electricity generation in order to satisfy the local demand. Three modes of generations which are ebbmode generation, flood-mode generation and double-mode generation is studied and the result showed that double-mode generation can produce the power generation that can meet the local demand. Besides, the potential sites for tidal barrage implementation also are identified which are Pulau Langkawi, Pulau Pinang, Lumut, Miri, Kota Kinabalu, Kudat, Lahad Datu, Tawau and Labuan. However, the tidal range become one the challenges since tides Malaysia doesn't meet the minimum tides requirement for tidal barrage and other solution or method for increasing the water level need to be studied.

The authors wish to express their gratitude to the Ministry of education for supporting the research under University Research Grant RDU130620 and providing the research facilities.

\section{References}

1. K.S. Lee, L.Y.S., Preliminary Investigation of the Potential of Harnessing Tidal Energy for Electricity Generation in Malaysia, (2008).

2. Salequzzaman, M., Prospects and Sustainability of Green Power: Case Study of Tidal Power.

3. Ali, R., I. Daut, and S. Taib, Renewable and Sustainable Energy Reviews, 16(6): p. 40474055 (2012).

4. Yun Seng Lim, S.L.K., Analytical assessments on the potential of harnessing tidal currents for electricity generation in Malaysia. 2010.

5. S.Bhargav reddy, B.A.K., International Journal of Engineering Trends and Technology (IJETT), 4(5) (2013).

6. K.S. Lee, L.Y.S., Simulation Studies on the Electrical Power Potential Harnessed by Tidal Current Turbines. 2009.

7. S.Bhargav reddy, B.A.K., International Journal of Engineering Trends and Technology (IJETT), 4(5), (2013).

8. Salequzzaman, M., Prospects and Sustainability of Green Power: Case Study of Tidal Power.

9. Department of Survey and Mapping Malaysia. Rekod Cerapan Air Pasang Surut 2007.

10. Department of Survey and Mapping Malaysia. Rekod Cerapan Air Pasang Surut 2008.

11. Department of Survey and Mapping Malaysia. Rekod Cerapan Air Pasang Surut 2009.

12. Department of Survey and Mapping Malaysia. Rekod Cerapan Air Pasang Surut 2010.

13. Department of Survey and Mapping Malaysia. Rekod Cerapan Air Pasang Surut 2011.

14. Taburan Penduduk dan Ciri-ciri Asas Demografi, J.P. Malaysia, Editor. 2010.

15. Malaysia Energy Statistic, S. Tenaga, Editor. 2014, Suruhanjaya Tenaga.

16. Google Maps, 2016 represents the location of Pulau Langkawi.

17. Google Maps, 2016 represents the location of Pulau Pinang.

18. Google Maps, 2016 represents the location of Lumut.

19. Google Maps, 2016 represents the location of Pelabuhan Kelang.

20. Google Maps, 2016 represents the location of Tanjung Keling.

21. Google Maps, 2016 represents the location of Kukup. 
22. Google Maps, 2016 represents the location of Johor Bahru.

23. Google Maps, 2016 represents the location of Sejingkat.

24. Google Maps, 2016 represents the location of Bintulu.

25. Google Maps, 2016 represents the location of Miri.

26. Google Maps, 2016 represents the location of Kota Kinabalu.

27. Google Maps, 2016 represents the location of Kudat.

28. Google Maps, 2016 represents the location of Sandakan.

29. Google Maps, 2016 represents the location of Lahad Datu.

30. Google Maps, 2016 represents the location of Tawau.

31. Google Maps, 2016 represents the location of Labuan.

32. Navionics Webapp: http://webapp.navionics.com/\#boating@4 